\title{
CAUSALITY RELATIONSHIP BETWEEN FINANCIAL INTERMEDIATION BY BANKS AND ECONOMIC GROWTH: EVIDENCE FROM SERBIA
}

\section{Saša Obradović, Milka Grbić*}

\begin{abstract}
:
This paper empirically examines the possible causal relationship between financial development and economic growth in Serbia. In this regard, the focus is on the development of financial intermediation by banks, considering the fact that the banking sector plays an important role in Serbian financial system. The empirical research is based on quarterly data for the period Q1 2004-Q4 2011 by using Toda-Yamamoto causality test. Our empirical findings suggest that process of economic growth contributes to process of financial deepening. On the other hand, the results indicate that there is a significant unidirectional causality that runs from both private enterprise credit to GDP and household credit to GDP to economic growth. Bidirectional causal relation is confirmed only between the share of bank credit to nonfinancial private sector in total domestic credit and economic growth rate.
\end{abstract}

Keywords: financial development, economic growth, Toda-Yamamoto Granger non-causality test, financial system, banking sector

JEL Classification: C12, C32, E51, G21

\section{Introduction}

There are two possible directions in defining the relations between the development of financial sector and economic growth: supply leading and demand following (Patrick, 1996). According to 'supply leading' approach the causal relation runs from financial development toward economic growth, whereby the creation and development of financial institutions and market enhance the offer of financial services, thus leading to the growth of economic activities. On the other hand, 'demand following' approach assumes that the growth of real economic activities leads to the increased demand for financial services, which, as a consequence, has the development of financial sector.

Although, the development of financial system varies across countries, the structure of financial system can be based on banks or securities market (Levine, 2002), depending on which of these two components of the financial system has stronger relative importance. Beck, Demirgüç-Kunt and Levine (2001) think that faster economic growth does not depend on whether the financial system of a certain country is based on banks or securities

* Saša Obradović, Ph.D., Associate Professor of Macroeconomics, Faculty of Economics, University of Kragujevac, Djure Pucara 3, 34000 Kragujevac, Serbia, e-mail: sobradovic@kg.ac.rs; Milka Grbić, Teaching and Research Assistant, Macroeconomics, Faculty of Economics, University of Kragujevac, Djure Pucara 3, 34000 Kragujevac, Serbia, e-mail: mgrbic@kg.ac.rs.

This paper is a part of Research Projects No. 179015 and No. 41010 financed by the Ministry of Science and Technological Development of the Republic of Serbia. 
market, but the important thing is the overall level of financial development and efficient regulations to protect the rights of investors. Pagano (1993) points out that financial system is a broad term, too. Therefore, in order to analyse its impact on the economic growth, a certain segment of the financial system has to be taken in consideration.

The financial systems in transitional countries are based on banks - approximately $85 \%$ of total assets of financial sector are accounted to bank assets (Backé et al., 2006), whereby the capital markets (especially the corporate bond market and stock market) are generally underdeveloped. Consequently, banking sector is the most important channel of financial intermediation in the case of Serbia, too. Compared to other transitional countries, the reforms of financial sectors in Serbia have started relatively late. During 2001 and 2002 large steps were taken in order to reform the banking sector in Serbia. The restructuring and privatization of the existing banks, as well as the entry of foreign banks conditioned the large expansion of commercial banking. The entry of foreign banks on the market increased the confidence in banking sector and improved many aspects of banking operations.

The importance of financial services provided by commercial banks for the economy as a whole is indicated by the size of banking sector, which is measured as a ratio of the consolidated total assets of commecial banks to the GDP. The consolidated assets of commercial banking sector in Serbia increased from 54.3\% GDP in 2002 to $115.6 \%$ in 2011. The largest share of assets in banking sector peaked in 2010 at $118.7 \%$ GDP. In the same year, the assets of banking sector in Romania, Bulgaria, Hungary and Slovenia were $67 \%, 105 \%, 135 \%$ and 142\%, respectively, National Bank of Serbia (2011). The aforementioned data suggest that the size of the banking sector in Serbia, measured by the ratio of consolidated banking assets to the GDP, does not fall behind the average values of the given indicators for the developed transitional economies.

One of the reasons why the financial system always attracts attention as an economic growth determinant lies in the fact that government can influence its development. The evidence of causality between financial development and economic growth can help governments to make priorities during the process of financial restructuring, Levine (1998). Hence, the aim of this paper is to research the existence and direction of the causality between financial development intermediation by banks on the economic growth on the example of Serbia.

The following section of the paper gives a short review of important empirical papers that study the impact of financial system development on the economic growth with a particular reference to the papers that exclusively analyse the impact of the financial intermediation by banks on the economic growth. Section 3 discusses the main methodological issues, while Section 4 offers a review of the results of the research. Section 5 provides conclusions.

\section{Review of Literature}

The research of correlation and causality between financial sector and economic growth has drawn attention of many authors in a significant number of papers during the last two decades. King and Levine (1993a) were among the first who, on the example of 80 countries for the period from 1960 to 1989, and by using the cross-country regression, analysed the connection between certain indicators of the size and activities of financial intermediaries 
on the one side, and the accumulation of capital rate and the increase of productivity as the main sources of economic growth on the other side. The results of that study show the strong positive correlation between higher levels of financial development and faster current and future economic growth rate. In addition, King and Levine (1993b) used the same sample in the same period of time to research ways by which financial systems influence long-term economic growth. The authors came to the conclusion that financial systems affect the entrepreneurial activities that lead to productivity improvements and that government policies toward financial systems may have an important causal effect on long-term economic growth.

Starting from La Porta et al. (1998), an increasing number of studies suggests that the differences in the legal systems of the countries affect the level of financial development with significant implications to economic growth. Levine (1998) found, by using a sample of 43 countries in the period from 1976 to 1993, a statistically significant relation between the development of banking sector and long-term rates of economic growth. In addition, the author in his analysis observed the impact of legal environment and made a conclusion that the variations in the levels of banking development among different countries could be explained by the differences in the rights of creditors and the efficiency of the judiciary. Similarly, Levin et al. (2000) confirmed the positive link between financial system development and economic growth introducing the indicators of legal system into the analysis. Considering the fact that laws have direct impact on financial intermediaries, the authors think that countries need to pursue the reforms of the legal system that will enable creditors to recover their claims from the debtors quickly, efficiently and transparently. Beck et al. (2000) examine the channels through which the development of financial intermediation affects economic growth using data for 63 countries in the period 19601995. They use the legal origin of countries as an instrumental variable to extract the exogenous component of financial intermediary development. The authors argue that financial intermediaries had large and positive effect on total factor productivity growth that enabled the growth of GDP.

Jung (1986) found out that in less developed countries, financial development caused the economic growth, whereas in developed countries, the economic growth caused financial development. Rousseau and Wachtel (1998) analysed data for five highly developed countries (Great Britain, the USA, Canada, Norway and Sweden) between the years of 1870 and 1929 and concluded that financial development was the main force which induced a rapid industrial transformation in the specified group of countries on the eve of the Great Depression. The financial development in the USA during the 19th century was the key factor of the economic growth in comparison to other countries, emphasized Rousseau and Sylla (2005). Burhop (2006) used time series analysis and data for Germany in the period from 1860 to 1913 and argued that the role of banks was the most important at early stages of industrial development of German economy.

In the aforementioned studies, the conclusions were drawn in general for all of the observed countries, while certain authors, during their analysis, paid special attention to heterogeneity of the countries in the sample. Gregorio and Guidotti (1995) had a sample of 98 countries in the period from 1960 to 1985 and they concluded that financial development had a positive impact on the economic growth, whereby the degree of that impact depended on the regions, period of time and income level. A positive impact was especially significant in the countries with medium to low income, whereas the impact 
of financial intermediation on the growth was mainly visible on the efficiency than on the volume of investments. In addition, they particularly examined the link between financial intermediation and economic growth for twelve Latin American countries in the period from 1950 to 1985. For the Latin American countries a negative correlation was discovered and the reason for that was found in the financial liberalization during the 1970s and 1980s under inadequate regulations. Odedokun (1996) used data for 71 countries in the period between 1960s and 1980s, applying time series regression analysis. He concluded that financial intermediation promoted growth of about $85 \%$ of the observed countries and that the growth-promoting effects of financial intermediation are practically invariant across the various regions. Demetriades and Hussein (1996) applied time series analysis on a sample of 16 countries for the period of 30 years (1960-1990), and they argued that the direction of causality differed across countries, proving that in quite a few countries, the economic growth caused financial development. Favara (2003) analysed the sample of 85 countries in the period 1960-1998 and he argued that with respect to the direction of causality between financial development and economic growth there is no obvious pattern that would apply to a particular geographical location, the level of economic development or institutional features.

The existing researches whose subjects of analysis are transitional countries are few and give conflicting results. Koivu (2002) analysed 25 countries in transition from 1993 to 2000 and pointed out that a large banking sector is not in itself something that promotes economic growth and that causality ran mostly from the direction of economic growth toward bank credit growth. Dawson (2003) on the example of 13 transitional countries in the Central and Eastern Europe found out that financial development had insignificant importance on the economic growth and ascertained that the economic growth in these countries was not limited by the underdeveloped financial sectors. Neimke (2003) proved that in transitional countries financial development had an impact on economic growth through increased investments and total factor productivity, which are two major channels of transmission. However, Mehl et al. (2005) did not confirm that financial development causes positive economic growth for 9 countries of Southeast Europe. Moreover, the relation between financial intermediation and economic growth turned out to be a negative one, which they explained that in a lower quality financial environment the expansion of financial intermediation did not affect the growth and efficiency. Cojocaru et al. (2011) analysed a sample of former socialist countries, and made a conclusion that credit to private sector had a positive impact on the economic growth, excluding the periods of high inflation. Gurgul and Lach (2011) found out that economic growth caused the development of banking sector in the case of Poland.

The aforementioned studies confirm Al-Yousif's (2002) conclusion that the nature of the relationship between financial development and economic growth differs for different countries, because each of them has specific economic policies whose success depends on, among other things, the efficiency of the institutions which implement those economic policies. In addition, different studies cover different periods as well as the use of different research methods. Therefore, the opinion of Luintel and Khan (1999) that, so far, there has been no consensus about the role of financial development in the process of economic growth, can be clearly confirmed. 


\section{Data and Methodology}

The researches show that the structure of financial system conditions the choice of the appropriate indicators of its development. Considering that the financial system in Serbia is based on banks, the analysis will include the indicators of the level of the development of financial intermediation by banks which approximates financial development of Serbian economy.

One of the most common indicators of financial depth and thus of the size of financial sector in the literature has been the ratio of broad money stock to nominal GDP (M2/ GDP). However, Demetriades and Hussein (1996) and Ghali (1999) point out that the increase of ratio M2/GDP in developing countries is often a reflection of the growth of currency held outside the banking system rather than an increase in the volume of bank deposits. That would reflect not the development of financial sector, but the degree of monetization in economy. Therefore, the ratio of bank deposit liabilities to nominal GDP (BDLY) is a better indicator of the financial depth, which excludes currency held outside the banking system from broad money stock (M2).

The ratio of bank credit to the private sector to GDP, as one of the indicators of activity of financial intermediaries points out to the role that financial sector, and especially deposit institutions have in the financing of economy (Levine and Zervos, 1998; Calderón and Lui, 2003). Following Beck et al. (2008), this indicator is decomposed to the ratio of bank credit to private enterprises to GDP (BCPEY) and ratio of bank credit to households to GDP (BCHY). In this analysis we also use the indicator of the development of financial intermediation which often serves to provide direct information about domestic assets allocation and that is ratio of bank credit to the nonfinancial private sector to total domestic credit (BCPSTC), (King and Levine, 1993a).

As the indicator of economic growth we use real GDP growth rate (previous quarter $=100$ ). The observed period is determined by the data that are available for Serbia, and it covers a time span from the first quarter of 2004 to the fourth quarter of 2011 (2004Q12011Q4). The monetary variables data are available on the website of the National Bank of Serbia (NBS), while the data for nominal GDP and real GDP growth rate have been taken from the database of the Statistical Office of the Republic of Serbia (RZS). All of the considered variables are expressed in local currency. As a program support for the research a software 'Eviews 6.0' have been used. In order to facilitate the monitoring of the empirical analysis Table 1 provides a summary of the used variables.

\section{Table 1}

\section{Short Description and Abbreviations of Examined Variables}

\begin{tabular}{|l|c|}
\hline Description of variable & Abbreviation for variable \\
\hline The real GDP growth rate & BDLY \\
\hline Ratio of bank deposit liabilities to nominal GDP & BCPEY \\
\hline Ratio of bank credit to private enterprises to GDP & BCHY \\
\hline Ratio of bank credit to households to GDP & BCPSTC \\
\hline $\begin{array}{l}\text { Ratio of bank credit to the nonfinancial private sector to total } \\
\text { domestic credit }\end{array}$ & \\
\hline
\end{tabular}


There are certain limits to the gathered data. The first one refers to the time dimension of data, because it is impossible to gather a long enough annual series of data for Serbia. Therefore, the data are given on a quarterly basis. The data can be relevant within constraints to be taken cautiously since they refer to the time period of only eight years. Secondly, it was a period of relatively unstable economic activities that was caused by the global economic recession in 2008 .

The research of causal relation between the development of financial intermediation by banks and economic growth has been carried out by using Toda-Yamamoto procedure of Granger non-causality test. Namely, the most frequently used operational definition of causality in econometrics is Granger definition (Granger, 1969), which says: variable $x$ is said to cause $y(x \rightarrow y)$, if the present value of variable $y$ can be predicted with greater accuracy based on the knowledge of the past values of variable $x$, with other conditions unchanged (ceteris paribus). It is well known that $F$ test of causality in VAR is not valid in the presence of non-stationary time series. However, Toda and Yamamoto (1995) proposed an alternative method for testing causality which unlike the standard Granger test implies the estimation of VAR model augmented with extra lags determined by the maximum order integration of the series under consideration. This method is applicable regardless the order of integration or cointegration rank of the observed variables.

Toda-Yamamoto procedure of Granger non-causality test basically involves four steps. Firstly, we need to find the highest order of integration in the variables $\left(\mathrm{d}_{\max }\right)$. For this purpose, we use an Augmented Dickey-Fuller (ADF) (Dickey and Fuller, 1981) unit root test, or to be more precise we test the autoregressive model:

$$
\Delta X_{t}=\delta_{0}+\delta_{1} t+\delta_{2} X_{t-1}+\sum_{i=1}^{m} \alpha_{i} \Delta X_{t-i}+\varepsilon_{t}
$$

Where: $X_{t}$ is a variable of interest $\left(\mathrm{Y}_{\mathrm{t}}, \mathrm{BDLY}_{\mathrm{t}}, \mathrm{BCPEY}_{\mathrm{t}}, \mathrm{BCHY}_{\mathrm{t}}, \mathrm{BCPSTC}_{\mathrm{t}}\right), t$ is time trend, $\varepsilon_{t}$ is an error term with white noise features, $\delta_{0}, \delta_{1}, \delta_{2}$ and $\alpha_{i}$ are set of parameters that are estimated. This unit root test is applied to the level variables as well as to their first differences. The null hypothesis tested is that the variable under investigation has a unit root, that is $\mathrm{H}_{0}: \delta_{2}=0$, against the alternative that it does not, that is $\mathrm{H}_{1}: \delta_{2}<0$. If the calculated statistics is greater than McKinnon's critical value, then the $\mathrm{H}_{0}$ or that the variable is not stationary, is not rejected. For the robustness of the obtained results of the analysis we also use one more unit root test, in order to eliminate the influence of autocorrelation errors, which was developed by Phillips and Perron (P-P) (1988).

Secondly, it is necessary to find the optimal number of lags for the VAR model (k). Thirdly, it is necessary to construct VAR of order $\mathrm{k}+\mathrm{d}_{\max }$ in levels, which in general, for two variables is:

$$
\begin{aligned}
& Y_{t}=a_{0}+\sum_{i=1}^{k+d_{\max }} a_{1 i} Y_{t-i}+\sum_{i=1}^{k+d_{\max }} b_{1 i} X_{t-i}+e_{Y_{t}} \\
& X_{t}=c_{0}+\sum_{i=1}^{k+d_{\max }} c_{1 i} X_{t-i}+\sum_{j=1}^{k+d_{\max }} d_{1 i} Y_{t-i}+e_{X_{t}}
\end{aligned}
$$

Where: $a_{0}$ and $c_{0}$ are the constants, $\mathrm{X}$ and $\mathrm{Y}$ are the variables, $a_{1 i}, b_{1 i}, c_{1 i}$ and $d_{1 i}$ are parameters of model, $k$ is the optimal lag order, $d_{\max }$ is the maximal order of integration of the series in the system, $e_{\mathrm{Yt}}$ and $e_{\mathrm{Xt}}$ are the white noise. We estimate VAR of order 
$\left(\mathrm{k}+\mathrm{d}_{\max }\right)$ using Seemingly Unrelated Regression (SUR) because the power of the Wald test improves when SUR technique is used for the estimation (Rambaldi and Doran, 1996).

Finally, we conduct Wald test (also known as modified Wald or MWald) for testing the significance of the parameters of a $\operatorname{VAR}\left(\mathrm{k}+\mathrm{d}_{\max }\right)$ model. Namely, to test the hypothesis that " $X$ does not Granger cause $Y$ " from equation ( $2 \mathrm{a})$, we test $\mathrm{H}_{0}: \mathrm{b}_{1 \mathrm{i}}=0$ against $\mathrm{H}_{1}: \mathrm{b}_{1 \mathrm{i}} \neq 0$, $(\mathrm{i}=1 \ldots \mathrm{k})$. Similarly, to test the hypothesis " $Y$ does not Granger cause $X$ " from equation ( $2 \mathrm{~b})$, we test, $\mathrm{H}_{0}: \mathrm{d}_{1 \mathrm{i}}=0$ against $\mathrm{H}_{1}: \mathrm{d}_{1 \mathrm{i}} \neq 0$, $(\mathrm{i}=1 \ldots \mathrm{k})$. Wald test is applied on the first $\mathrm{k}$ coefficient matrices, whereas the coefficient matrices of the last $\mathrm{d}_{\max }$ lagged vectors in the model are ignored (since they are regarded as zeros). In that case the Wald test statistics follows asymptotic $\lambda^{2}$ distribution with $m$ degrees of freedom and it can be applied even if $\mathrm{X}_{t}$ and $Y_{t}$ are $I(0), I(1)$ or $I(2)$, cointegrated or non-cointegrated with a condition that the order of integration does not exceed the true lag length of the model (Toda and Yamamoto, 1995).

\section{The Results of the Research}

In order to eliminate the seasonal impact on variables, a procedure of seasonal adjustment time series was conducted by using X-12 ARIMA method. The time series values were transformed into logarithmic form (apart from series of the rate of growth of real GDP (Y) which in its structure has negative values). Then, the ADF and P-P unit root tests are applied to see the integrated properties of time series variables. The presence of unit root is tested using the model where trend and intercept are included as well as model where only intercept is included. The results of ADF and P-P unit root tests are shown in Table 2a. They indicate that the null hypothesis of non-stationary is rejected for time series $\mathrm{Y}$ and $\mathrm{BCHY}$, that is, these series are stationary in levels. The remaining three time series (BDLY, BCPEY and BCPSTC) have unit root in levels when both are included trend and intercept, or when only intercept is included. This indicates that these series are nonstationary at their level form.

\section{Table 2a}

The Results of ADF and Phillips-Perron Unit Root Tests (Level) Source: Calculation done by the authors

\begin{tabular}{|c|c|c|c|c|}
\hline Variable & $\begin{array}{l}\text { Deterministic } \\
\text { components }\end{array}$ & ADF Statistic & $\begin{array}{l}\text { Deterministic } \\
\text { components }\end{array}$ & P-P Statistic \\
\hline $\mathbf{Y}$ & $\begin{array}{l}\text { Trend and intercept } \\
\text { Intercept }\end{array}$ & $\begin{array}{l}-5.053647^{*} \\
-4.083083^{*}\end{array}$ & $\begin{array}{l}\text { Trend and intercept } \\
\text { Intercept }\end{array}$ & $\begin{array}{l}-5.068413^{*} \\
-4.086267^{*}\end{array}$ \\
\hline BDLY & $\begin{array}{l}\text { Trend and intercept } \\
\text { Intercept }\end{array}$ & $\begin{array}{l}-1.619450 \\
-1.913208\end{array}$ & $\begin{array}{l}\text { Trend and intercept } \\
\text { Intercept }\end{array}$ & $\begin{array}{l}-0.810690 \\
-1.735616\end{array}$ \\
\hline BCPEY & $\begin{array}{l}\text { Trend and intercept } \\
\text { Intercept }\end{array}$ & $\begin{array}{l}-2.247344 \\
-0.867568\end{array}$ & $\begin{array}{l}\text { Trend and intercept } \\
\text { Intercept }\end{array}$ & $\begin{array}{l}-1.496326 \\
-1.135929\end{array}$ \\
\hline BCHY & $\begin{array}{l}\text { Trend and intercept } \\
\text { Intercept }\end{array}$ & $\begin{array}{l}-2.154962 \\
-4.902294^{*}\end{array}$ & $\begin{array}{l}\text { Trend and intercept } \\
\text { Intercept }\end{array}$ & $\begin{array}{l}-5.215539^{*} \\
-19.05775^{*}\end{array}$ \\
\hline BCPSTC & $\begin{array}{l}\text { Trend and intercept } \\
\text { Intercept }\end{array}$ & $\begin{array}{l}-0.517999 \\
-1.487516\end{array}$ & $\begin{array}{l}\text { Trend and intercept } \\
\text { Intercept }\end{array}$ & $\begin{array}{l}-0.716484 \\
-1.588369\end{array}$ \\
\hline
\end{tabular}

Note: the number of lags in model was determined by Schwarz information criterion.

Asterisk $(*),(* *),\left({ }^{* *}\right)$ denote statistically significant at $1 \%, 5 \%$ and $10 \%$ levels, respectively. 
Further, we perform the ADF and P-P unit root tests on the first differences of BDLY, BCPEY and BCPSTC. The null hypothesis of non-stationary is rejected at the first difference of each variable as shown in Table $2 \mathrm{~b}$. According to the results of unit root tests we draw a conclusion that the given time series are integrated of order one, I(1), that is, non-stationary in their levels, and stationary in their first differences.

Table 2b

The Results of ADF and Phillips-Perron Unit Root Tests (1st Difference) Source: Calculation done by the authors

\begin{tabular}{|l|l|l|l|l|}
\hline Variable & \multicolumn{1}{|c|}{$\begin{array}{c}\text { Deterministic } \\
\text { components }\end{array}$} & ADF Statistic & \multicolumn{1}{c|}{$\begin{array}{c}\text { Deterministic } \\
\text { components }\end{array}$} & P-P Statistic \\
\hline $\mathbf{\Delta B D L Y}$ & $\begin{array}{l}\text { Trend and intercept } \\
\text { Intercept }\end{array}$ & $\begin{array}{l}-2.996943 \\
-2.754040^{* * *}\end{array}$ & $\begin{array}{l}\text { Trend and intercept } \\
\text { Intercept }\end{array}$ & $\begin{array}{l}-3.005398 \\
-2.743302^{* * *}\end{array}$ \\
\hline \multirow{2}{*}{$\mathbf{B C P E Y}$} & Trend and intercept & $-3.706986^{* *}$ & $\begin{array}{l}\text { Trend and intercept } \\
\text { Intercept }\end{array}$ & $\begin{array}{l}-3.534463^{* * *} \\
-3.581075^{* *}\end{array}$ \\
\hline \multirow{2}{*}{ Intercept } & $-3.752914^{*}$ & $-3.497487^{* * *}$ & $\begin{array}{l}\text { Trend and intercept } \\
\text { Intercept }\end{array}$ & $\begin{array}{l}-3.487586^{* * *} \\
-2.243039\end{array}$ \\
\hline
\end{tabular}

Note: The number of lags in model was determined by Schwarz information criterion.

Asterisk $\left({ }^{*}\right),\left({ }^{* *}\right),\left({ }^{* *}\right)$ denote statistically significant at $1 \%, 5 \%$ and $10 \%$ levels, respectively.

Given that the maximal order of integration $\left(\mathrm{d}_{\max }\right)$ equals 1 , we next determine the optimal lag length (k). For that we rely on Akaike information criterion (AIC) and Schwarz information criterion (SIC). On the basis of the results, all of the information criteria give unambiguous answer, pointing to the lag length 1 . However, to remove the present series correlation in the model, the lag length goes to 2 .

Considering that 3 of 5 variables are stationary in the first differences, that means that is $\mathrm{d}_{\max }=1$, whereas $\mathrm{k}=2$. Therefore, in order to examine causality between financial intermediation by banks and economic growth, VAR model is constructed, consisting of five variables in levels, of order $\mathrm{k}+\mathrm{d}_{\max }=1+2=3$. By using the framework of seemingly unrelated regression (SUR) for a $\operatorname{VAR}(3)$, we estimate the following system of equations:

$$
\left[\begin{array}{l}
Y_{t} \\
B D L Y_{t} \\
B C P E Y_{t} \\
B C H Y_{t} \\
B C P S C T_{t}
\end{array}\right]=A_{0}+A_{1}\left[\begin{array}{l}
Y_{t-1} \\
B D L Y_{t-1} \\
B C P E Y_{t-1} \\
B C H Y_{t-1} \\
B C P S C T_{t-1}
\end{array}\right]+A_{2}\left[\begin{array}{l}
Y_{t-2} \\
B D L Y_{t-2} \\
B C P E Y_{t-2} \\
B C H Y_{t-2} \\
B C P S C T_{t-2}
\end{array}\right]+A_{3}\left[\begin{array}{l}
Y_{t-3} \\
B D L Y_{t-3} \\
B C P E Y_{t-3} \\
B C H Y_{t-3} \\
B C P S C T_{t-3}
\end{array}\right]+\left[\begin{array}{l}
e_{Y} \\
e_{B D L Y} \\
e_{B C P E Y} \\
e_{B C H Y} \\
e_{B C P S C T}
\end{array}\right]
$$

The Granger non-causality hypotheses can be tested using MWald test on the following sets of restrictions: 
I. $\quad H_{0}: a_{12}{ }^{(1)}=a_{12}{ }^{(2)}=0 \rightarrow B D L Y$ does not Granger cause $Y$

II. $\quad H_{0}: a_{21}{ }^{(1)}=a_{21}{ }^{(2)}=0 \rightarrow Y$ does not Granger cause BDLY

III. $H_{0}: a_{13}{ }^{(1)}=a_{13}{ }^{(2)}=0 \rightarrow B C P E Y$ does not Granger cause $Y$

IV. $H_{0}: a_{31}{ }^{(1)}=a_{31}{ }^{(2)}=0 \rightarrow Y$ does not Granger cause BCPEY

V. $\quad H_{0}: a_{14}{ }^{(1)}=a_{14}{ }^{(2)}=0 \rightarrow B C H Y$ does not Granger cause $Y$

VI. $H_{0}: a_{41}{ }^{(1)}=a_{41}{ }^{(2)}=0 \rightarrow$ Ydoes not Granger cause BCHY

VII. $H_{0}: a_{15}{ }^{(1)}=a_{15}{ }^{(2)}=0 \rightarrow B C P S C T$ does not Granger cause $Y$

VIII. $H_{0}: a_{51}{ }^{(1)}=a_{51}{ }^{(2)}=0 \rightarrow Y$ does not Granger cause BCPSCT

The existence of causality is confirmed by rejecting null hypothesis in case of MWald statistic test that is statistically significant at $1 \%, 5 \%$ or $10 \%$ significance levels. The results of testing five-variate VAR(3) model are given in Table 3.

The results of tests of restrictions from a VAR estimated by the procedure proposed by Toda and Yamamoto (1995) are mixed. Null hypothesis that BDLY does not Granger cause $\mathrm{Y}$ is not rejected, which means that causal relation in Granger sense from the direction of the ratio of bank deposit liabilities to GDP toward economic growth rate does not exist. Otherwise, the results show that there is a unidirectional causal relation that runs from the direction of economic growth rate toward the ratio of bank deposit liabilities to GDP at 5\% significance level. In this context we could agree with the findings of Gurgul and Lach (2011) and Koivu (2002). However, when considering the share of bank credit to private sector the nature of causality is completely different. It is confirmed that there is a unidirectional causality relation between the share of bank credit to private enterprises in GDP and economic growth rate (for the larger number of countries, the same findings are confirmed by Beck, 2008); the share of bank credit to households in GDP and economic growth rate. Both results are significant at $1 \%$ and $5 \%$ significance levels, respectively. On the other hand, no evidence of reverse causality from the economic growth to private enterprise and household credit is found. In the case of relation between the ratio of bank credit to nonfinancial private sector to total domestic credit and economic growth rate, the analysis identified bidirectional causal relation at $10 \%$ significance level. Similarly, Cojocaru (2011) concludes that credit to the private sector plays a positive and economically large role in spurring economic growth. Since the strategic orientation of the Serbian government is the development of small and medium enterprises, whose sources of funding are mainly banks, the need for adequate regulation and supervision is particularly emphasised, so that the positive effects of the allocation of financial resources are sustainable in the long term. 
Table 3

The Results of the Toda -Yamamoto Granger Non-causality TestSource: Calculation done by the authors

\begin{tabular}{|c|c|c|c|c|c|}
\hline Null Hypothesis & Lag (k) & $k+d_{\max }$ & $\lambda^{2}$ - statistics & p-value & $\begin{array}{l}\text { Direction } \\
\text { of Causality }\end{array}$ \\
\hline $\begin{array}{l}\text { BDLY does not Granger cause } Y \\
\text { Y does not Granger cause BDLY }\end{array}$ & 2 & $2+1=3$ & $\begin{array}{l}3.459293 \\
\mathbf{7 . 7 2 7 1 1 5 * *}\end{array}$ & $\begin{array}{l}0.1773 \\
\mathbf{0 . 0 2 1 0}\end{array}$ & $B D L Y \leftarrow Y$ \\
\hline $\begin{array}{l}\text { BCPEY does not Granger cause } Y \\
\text { Y does not Granger Cause BCPEY }\end{array}$ & 2 & $2+1=3$ & $\begin{array}{l}12.45530 * \\
4.054830\end{array}$ & $\begin{array}{l}\mathbf{0 . 0 0 2 0} \\
0.1317\end{array}$ & BCPEY $\rightarrow \mathbf{Y}$ \\
\hline $\begin{array}{l}\text { BCHY does not Granger cause } Y \\
\text { Y does not Granger Cause BCHY }\end{array}$ & 2 & $2+1=3$ & $\begin{array}{l}\mathbf{8 . 2 8 8 4 9 7 * *} \\
3.260646\end{array}$ & $\begin{array}{l}\mathbf{0 . 0 1 5 9} \\
0.1959\end{array}$ & $\mathrm{BCHY} \longrightarrow \mathrm{Y}$ \\
\hline $\begin{array}{l}\text { BCPSTC does not Granger cause } Y \\
\text { Y does not Granger cause BCPSTC }\end{array}$ & 2 & $2+1=3$ & $\begin{array}{l}5.855410 * * * \\
5.723306 * * *\end{array}$ & $\begin{array}{l}0.0535 \\
0.0572\end{array}$ & BCPSTC $\leftrightarrow Y$ \\
\hline
\end{tabular}

Note: Asterisk $(*),(* *),\left({ }^{* * *}\right)$ denote statistically significant at $1 \%, 5 \%$ and $10 \%$ levels, respectively.

It has already been mentioned in the introduction that banking sector provides the most important channel of financial intermediation in Serbia. In this regard, the primary goal of the Serbian banking sector over the next decade should be to maintain the high growth potential and stability of the banking sector. It means the continuation of the current strategy with the necessary increase of the competition within the sector and between other forms of financial intermediation. Maintaining the high growth potential of the banking sector should open the possibility of its internal diversification. Preferably, the activation of diverse forms of banking - savings banks in the deposit market and microfinance institutions in the credit market. These forms of intermediation should reduce the cost of financial intermediation and increase the availability of financial resources.

\section{Conclusion}

The main goal of the paper was to find out if there is a causal relationship between the financial intermediation by banks and economic growth in Serbia. The intention was to cover the most important aspects of financial development, so the analysis included four indicators of the development of financial intermediation whereby the real GDP growth rate is used as a proxy for economic growth. The causality between the indicators of the development of financial intermediation by banks and economic growth rate is examined by using Toda-Yamamoto Granger non-causality test, an innovative and more efficient econometric methodology to test the direction of causality.

The conducted empiric research for many countries around the world shows that causal relation between financial development and economic growth can be unidirectional or bidirectional, as well as that the mentioned causality does not have to exist at all. Our empirical findings suggest that process of economic growth contributes to process of financial deepening. On the other hand, the results indicate that there is a significant unidirectional causality that runs from both private enterprise credit to GDP and household credit to GDP to economic growth. Bidirectional causal relation is confirmed between the share of bank credit to nonfinancial private sector in total domestic credit and economic 
growth rate. Therefore, the analysis shows that in the case of Serbia, there is no universal conclusion that financial development promotes the economic growth, and vice versa, but the causal relation depends on which of the indicators of the development of financial intermediation are observed.

According to the results, banking sector in Serbia has an important role in the process of economic growth, especially when it comes to bank credits to nonfinancial private sector. In this regard, the results of this study should be very helpful to policymakers for adopting the adequate reforms to promote the financial system development and economic growth. In terms of the future explorations, it would be interesting to research the relation between credit activities of banks and particular sector components of GDP, for example, sector of services or manufacturing industry. This is likely to improve upon our results and may even provide more robust conclusions.

\section{References}

Al-Yousif, Y. K. (2002), "Financial Development and Economic Growth: Another Look at the Evidence from Developing Countries." Review Financial Economics, Vol. 11, No. 2, pp. 131-150.

Backé, P., Égert, B., Zumer, T. (2006), "Credit Growth in Central and Eastern Europe: New (Over) Shooting Stars?" ECB Working Paper Series No. 687.

Beck, T., Levine R., Loayza N. (2000), "Finance and the Sources of Growth." Journal of Financial Economics, Vol. 58, No. 1-2, pp. 261-300.

Beck, T., Demirgüç-Kun, A., Levine, R. (2001), "The Financial Structure Database", In Financial Structure and Economic Growth: A Cross-Country Comparison of Banks, Markets and Development, Edited by Aslõ Demirgüç-Kunt and Ross Levine, The MIT Press, pp. 17-80.

Beck, T., Büyükkarabacak, B., Rioja, F., Valev, N. (2008), "Who Gets the Credit? And does it Matter?" Policy Research Working Paper. No. 4661. Washington: World Bank.

Burhop, C. (2006), "Did Banks Cause the German Industrialization." Explorations in Economic History, Vol. 43, No. 1, pp. 39-63.

Calderón, C., Liu, L. (2003), "The Direction of Causality between Financial Development and Economic Growth." Working Paper No. 184. Central Bank of Chile.

Cojocaru, L., Hoffman, S., Miller, J. (2011), "Financial Development and Economic Growth in Transition Economies: Empirical Evidence from the CEE and CIS Countries." Working Paper No. 2011-22. Department of Economics, University of Delaware.

Dawson, P. J. (2003), "Financial Development and Growth in Economies in Transition." Applied Economics Letters, Vol. 10, No. 13, pp. 833-836.

Demetriades, P. O., Hussein, K. A. (1996), “Does Financial Development Cause Economic Growth? Time Series Evidence from 16 Countries." Journal of Development Economics, Vol. 51, No. 2, pp. 387-411.

Dickey, D. A., Fuller, W. A. (1981), "Likelihood Ratio Statistics for Autoregressive Time Series with a Unit Root." Econometrica, Vol. 49, No. 4, pp. 1057-1072.

Favara, G. (2003), "An Empirical Reassessment of the Relationship between Finance and Growth." Working Paper No. 03/123. Washington: International Monetary Fund.

Ghali, H. K. (1999), "Financial Development and Economic Growth: The Tunisian Experience." Review of Development Economics, Vol. 3, No. 3, pp. 310-322.

Granger, C. W. J. (1969), "Investigating Causal Relations by Econometric Models and Cross-spectral Methods." Econometrica, Vol. 37, No. 3, pp. 424-438. 
Gregorio, J., Guidotti, P. E. (1995), "Financial Development and Economic Growth." World Development, Vol. 23, No. 3, pp. 433-448.

Gurgul, H., Lach, L. (2011), “Financial Development and Economic Growth in Poland in Transition: Causality Analysis." MPRA Paper No. 38034.

Jung, W. S. (1986), "Financial Development and Economic Growth: International Evidence." Economic Development and Cultural Change, Vol. 34, No. 2, pp. 333-346.

King, R.G., Levine, R. (1993a), "Finance and Growth: Schumpeter Might Be Right." Quarterly Journal of Economics, Vol. 108, No. 3, pp. 717-737.

King, R.G., Levine, R. (1993b), "Finance, Entrepreneurship and Growth: Theory and Evidence." Journal of Monetary Economics, Vol. 32, No. 3, pp. 513-542.

Koivu, T. (2002), “Do Efficient Banking Sectors Accelerate Economic Growth in Transition Economies?" Discussion Paper No. 14. Bank of Finland, Institute for Economies in Transition.

La Porta, R., Lopez-de-Silanes, F., Shleifer, A., Vishny, R. W. (1998), "Law and Finance." Journal of Political Economy, Vol. 106, No. 6, pp. 1113-1155.

Levine, R. (1998), "The Legal Environment, Banks, and Long-Run Economic Growth." Journal of Money, Credit, and Banking, Vol. 30, No. (3, Pt. 2), pp. 596-613.

Levine, R., Zervos, S. (1998), "Stock Markets, Banks, and Economic Growth." The American Economic Review, Vol. 88, No. 3, pp. 537-558.

Levine, R., Loayza, N., Beck, T. (2000), "Financial Intermediation and Growth: Causality and Causes." Journal of Monetary Economics, Vol. 46, No. 1, pp. 31-77.

Levine, R. (2002), "Bank-Based or Market-Based Financial Systems: Which Is Better?" Journal of Financial Intermediation, Vol. 11, No. 4, pp. 398-428.

Luintel, K. B., Khan, M. (1999), "A Quantitative Reassessment of the Finance Growth Nexus: Evidence from a Multivariate VAR." Journal of Development Economics, Vol. 60, No. 2, pp. 381-405.

Mehl, A., Vespro, C., Winkler, A. (2005), "The Finance-Growth Nexus and Financial Sector Environment: New Evidence from Southeast Europe." Conference on European Economic Integration, Austrian National Bank, Vienna.

National Bank of Serbia (2011), Annual Report on Activities and Results, http://www.nbs.rs/export/ sites/default/internet/english/90/90_4/annual_report_2011.pdf

Neimke, M. (2003), "Financial Development and Economic Growth in Transition Countries." IEE Working Papers 173.

Odedokun, M. O. (1996), "Alternative Econometric Approaches for Analyzing the Role of the Financial Sector in Economic Growth: Time-series evidence from LDCs." Journal of Development Economics, Vol. 50, No. 1, pp. 119-146.

Pagano, M. (1993), "Financial Markets and Growth: An Overview." European Economic Review, Vol. 37, No. 2-3, pp. 613-622.

Patrick, H. T. (1966), "Financial Development and Economic Growth in Underdeveloped Countries." Economic Development and Cultural Change, Vol. 14, No. 2, pp. 174-189.

Phillips, P. C. B., Perron, P. (1988), "Testing for a Unit Root in Time Series Regression." Biometrika, Vol. 75, No. 2, pp. 336-346.

Rambaldi, A. N., Doran, H. E. (1996), "Testing for Granger Non-Causality in Cointegrated Systems Made Easy." Working Paper in Econometrics and Applied Statistics No. 88, University of New England. 
Rousseau, P., Wachtel, P. (1998), "Financial intermediation and Economic Performance: Historical Evidence from Five Industrialized Countries." Journal of Money, Market and Banking, Vol. 30, No. 4, pp. 657-678.

Rousseau, P. L., Sylla, R. (2005), “Emerging Financial Markets and Early US Growth." Explorations in Economic History, Vol. 42, No. 1, pp. 1-26.

Toda, H.Y., Yamamoto, T. (1995), "Statistical Inferences in Vector Autoregressions with Possibly Integrated Processes." Journal of Econometrics, Vol. 66, No. 1-2, pp. 225-250. 